\title{
総説
}

||||||||||||||||||||||||||||||||||||||||

\section{FLASH Radiotherapy}

\author{
岩田宏満 1,2, , 芝本雄太 ${ }^{2}$ \\ 1 名古屋市立大学医学部附属西部医療センター陽子線治療科, \\ 2 名古屋市立大学大学院医学研究科放射線医学分野 \\ ${ }^{\dagger}$ h-iwa-ncu@nifty.com
}

FLASH Radiotherapy は超高線量率照射のことであり，「障害が軽減される特性」を有している。 そのため, 放射線治療の今までの概念を覆すものであり，臨床応用ができれば，放射線治療分野 でパラダイムシフトとなる潜在的可能性を秘めている。本総説では, 背景, 生物学的内容, メ力 ニズムや臨床応用へ向けた取り組みなどについて紹介する。

Key Words: ultra-high dose rate irradiation, conventional dose rate irradiation, normal tissue damage, oxygen depletion, proton therapy

\section{1.はじめに}

がん治療の一つである放射線治療は，欧米な どの先進国では，がん患者の $60 \%$ 以上に対して 施行されている。根治治療や緩和治療など集学 的治療の一手として, 重要な役割を担っている。 残念ながら，日本においては，まだその割合は $30 \%$ 未満と低い状況で, 患者や医療従事者側へ の更なる啓蒙活動が必要である。放射線治療 は，より根治度を上げる(殺細胞効果を上げる) ために, 線量増加が考慮されるが, 腫瘍周囲の 正常組織に対する急性期及び晚期の障害を同時 に検討する必要があり, 耐容線量を考虑すると, 照射可能な放射線線量には限界がある。近年, 薬物治療の発展などから, 進行がんであっても, 長期生存が増加するにつれて, 放射線治療に起 因する晚期障害が発生し，これによる患者の生 活の質 (quality of life, QOL) に重大な影響を及 ぼすことが報告されている ${ }^{1)}$ 。そのため，放射 線治療の戦略としては, いかに治療効果比をあ げるか, つまり，高い抗腫瘍効果を維持しなが ら，いかに周囲正常組織に対する障害を抑える かが鍵となる。テクノロジーの進歩で, X 線治 療も照射技術が向上し, 定位放射線治療や強度
変調放射線治療などの発展によって, ピンポイ ントな位置精度で正常組織の線量低減ができる ようになってきた。また, さらなる治療効果比 の改善を求め, 陽子線治療や炭素イオン線治療 が活用され，多くの良好な治療成績が報告され ている。さらにこれら粒子線に関しては, 強度 変調陽子線治療のような最先端の技術で, X 線 治療では得られない, ターゲットへの集中性を より担保しながら, 低〜中等度の線量域の軽減 を図る，ということができるようになってきた。 これらの最先端技術は, 臨床の場において, 保 険診療や先進医療として活用され, 良好な成績 が報告され, 今後の放射線治療の発展のため, 日々研究も盛んに抗こなわれている。しかし, これらの技術を駆使したとしても，がんに対す る線量増加には限界があり, また周囲組織への 影響を完全に避けることは不可能である。例え ば，進行肺癌においては，粒子線治療は，X線 治療と比較して, 毒性軽減が期待され, 集学的 治療の一環として, 化学療法と陽子線治療が併 用されるようになり, 良好な成績・毒性軽減, また良好な QOL 維持も報告されているが2)，い まだに標準治療としては議論の余地のある状態 である。さらに効果を期待するには, 線量増加 


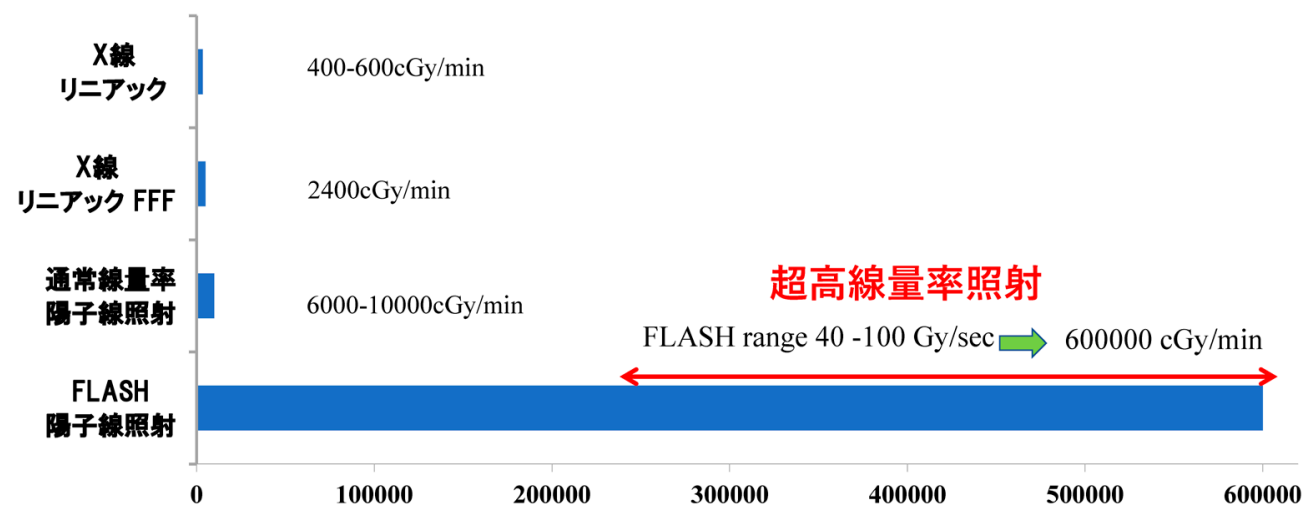

図 1 Difference in dose rate between FLASH and conventional dose rate irradiation (Color online).

や寊分割照射などが安全に行うことができるよ うな戦略や免疫チェックポイント阻害剂の併用 を,さらに考慮する必要がある。

これらを踏まえた上で，近年，「FLASH」と 呼ばれる，いわゆる「超高線量率照射」が瞬く 間に，放射線治療業界で話題になり，米国放 射線腫瘍学会の annual meeting 2019 の Cancer Breakthroughs の中でも紹介され, 次世代の革 新的な技術・照射として位置づけられるように なってきた。この革新的な照射技術・方法は, 放射線治療の今までの概念を覆すものであり, 臨床応用ができれば，放射線治療分野でパラダ イムシフトとなる潜在的可能性を秘めていると 考えられる。本総説では, この「FLASH Radiotherapy (FLASH-RT)」に関して, 背景, 生物学 的内容, メカニズムや臨床応用へ向けた取り組 みなどについて紹介する。

\section{2.「FLASH」に関する研究の背景}

高線量率に関する研究は, 1960-70 年代から 行われ，超高線量率で照射した哺乳動物の細胞 が, 従来の線量率で照射された細胞と比較して 生存率が高くなる，つまり正常組織が保護され ることがすでに発見されていた ${ }^{3,4)}$ 。しかしな がら, 当時においては, 臨床で使用されている 放射線治療機器では, 到底実現が不可能と考え られ，一旦研究も下火になっていった。しかし

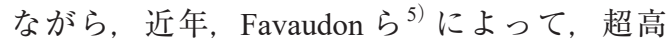

線量率照射による，この「障害が軽減される特 性」が再発見され，「FLASH」と名付けられた。 この FLASH に関する報告は, 電子線, X 線, 陽子線によるものがあるが，現状では大半が電 子線によるものであることは知っておいていた だきたい。図 1 に線量率の違いの例を示す。

\section{3.「FLASH」効果の正常組織に対する生物学 的内容}

Favaudonらは, $4.5 \mathrm{MeV}$ のパルス電子線を 用いて, C57BL/6J マウスの両側胸郭照射を行 い, 肺線維化形成について報告した ${ }^{5)}$ 。従来 の線量率 $(\leq 0.03 \mathrm{~Gy} / \mathrm{s}, \mathrm{CONV}-\mathrm{RT}$, conventional RT）で $17 \mathrm{~Gy}$ の 1 回照射をマウスの胸部に行う と, 照射から 36 週後に中〜重度の肺線維症の 領域を誘発させることを彼らは示した。対照 的に, 同じ線量の照射を超高線量率 (40-60 Gy/ s, FLASH-RT) で受けると, 肺線維症の誘発が 明白に低減された。CONV-RT の実施後に認め られる同程度のレベルの肺線維症を誘発するに は, FLASH-RTでは, より高い線量 $30 \mathrm{~Gy}$ が必 要であった。

Montay らは, FLASH-RT を用いた全脳照射を 行うと, CONV-RT と比較して神経防護効果があ ることを報告した ${ }^{6)}$ 。マウスに $0.1 \mathrm{~Gy} / \mathrm{s}-500 \mathrm{~Gy} / \mathrm{s}$ の様々な線量率で $10 \mathrm{~Gy}$ を電子線で照射し, 照 射から2ヶ月後に, 記憶の温存を解析した。 $0.1 \mathrm{~Gy} / \mathrm{s}$ で照射されたマウスは, 照射しなかっ 
た対照動物と比較して, 記憶の温存が有意に悪 く, $30 \mathrm{~Gy} / \mathrm{s}$ 以上の線量率で照射すると, 有意に 空間記憶の温存が認められた。さらに, $100 \mathrm{~Gy} / \mathrm{s}$ を超える線量率を照射したマウスと無照射マウ スの間で, 記憶の温存に統計的な差は認められ なくなった。Simmons ら ${ }^{7)}$ は, 同様の照射実験 を行い, FLASH-RTによる海馬の樹状突起棘の 温存, 神経炎症の減少などを報告している。

超高線量率 $(67 \mathrm{~Gy} / \mathrm{s})$ で放射線誘発性皮膚反 応を有意に低減できることが, ラットですでに 観察されていた ${ }^{8)}$ 。近年は, これらの照射実験 がミニブタやネコなど, より高次の哺乳動物に 拡大してきた。Vozenin ら ${ }^{9)}$ は, 1 頭のミニブ 夕の背部の直径 $26 \mathrm{~mm}$ の円形パッチ 10 箇所に, $22 \mathrm{~Gy}$ から $34 \mathrm{~Gy}$ を線量率 $300 \mathrm{~Gy} / \mathrm{s}$ の FLASH-RT と，また $0.083 \mathrm{~Gy} / \mathrm{s}$ の CONV-RTをそれぞれ照 射し，48 週間後に調べたところ，FLASH-RTに 対しては高い忍容性を示し, 照射した部位に軽 度の皮膚脱色が見られたのみであった。対照的 に, CONV-RT を照射した部位では, 明確な線維 壊死性病変を認め, 2 つの照射法の間の等価線 量の違いは, 線量に関して $20 \%$ 以上であった。

また, マウスの腹部に照射した後に正常 組織が温存され, 生存率が上昇することが, $16 \mathrm{MeV}$ 電子ビームを発生させる改造した臨床 用リニアックを使って Levyらにより実証され た ${ }^{10)} 。 0.079 \mathrm{~Gy} / \mathrm{s}$ での CONV-RT と $216 \mathrm{~Gy} / \mathrm{s}$ での FLASH-RT をそれぞれ照射すると，前者では 10 日後にすべてのマウスが生存できなかったが, 後者では90日後でも 9 割が生存していた，また 消化管の腺窩細胞の障害に差が認められた。

これらの前臨床研究の結果をみると, FLASH-RT による可能性に期待してしまうが, 逆に, FLASH-RT 後に正常組織の有意な温存効 果がないことを報告している研究が複数あるこ とも無視することはできない11,12)。しかし，こ れらは, ビームスライスの線量率の違い, 研究 対象となったエンドポイントの違いや, 生物学 的状態の違い (ゼブラフィッシュの胚の受精か らの期間が長かった）などが指摘されている。
上記以外にも，特に近年に多数の研究におい て, FLASH-RTによる放射線誘発の障害が軽減 されることが続々と示されている ${ }^{13-15) 。 ~}$

\section{4.「FLASH」効果の腫瘍細胞に対する生物学 的内容}

上記のような，正常組織に対する障害が軽 減されることに加えて, FLASH-RT は, CONVRT 後に認められるものと同程度 (もしくはそ れ以上）の抗腫瘍応答が得られるという報告が 多数ある。Favaudon ら ${ }^{5)}$ はヌードマウスに移 植したヒト HBCx-12A と HEp-2 腫瘍ならびに C57BL/6J マウスに移植した TC-1 (Luc+) 腫瘍 の増殖を評価したところ, CONV-RT と FLASHRT に治療効果の差を認めなかった。Bourhis $ら^{16)}$ が行った研究では, H454-luc+GBM 細胞 をヌードマウスの線条体内に移植し，3 日後 に, 全脳照射を 1 回パルス $(1.8 \mu \mathrm{s})$ FLASH-RT もしくは CONV-RT $(0.1 \mathrm{~Gy} / \mathrm{s})$ を, $10 \mathrm{~Gy} 1$ 回照 射, $8 \mathrm{~Gy}$ の 3 回照射, もしくは $5 \mathrm{~Gy}$ の 5 回照射 を行った(分割照射は24 時間の間隔)。腫瘍量 を評価すると, いずれの分割照射においても, FLASH-RT と CONV-RT との間に有意な差を認 めなかった。Vozenin ら ${ }^{9)}$ は, ネコの鼻平面の 扁平上皮癌を治療する際に, 6 頭のネコに対し て FLASH-RTを25-41Gy照射した。6頭のネ コは, 治療に対して極めて良好に応答し, 腫瘍 は完全寛解し, 最大線量で治療を受けたネコに おいて, 照射部の周囲に湿性落屑を示したのみ で, 皮膚障害は非常に少なかった。上記以外に も, FLASH-RT の抗腫瘍効果が CONV-RT と比 較して同等になることが示されている ${ }^{10,17) 。 ~}$

\section{5.「FLASH」効果の in vitro に対する生物学的 内容}

In vivo における「FLASH-RT」の影響を検討・ 証明するためにも， in vitroに対する影響も同 様であることが期待されるが, 細胞生存に関し て FLASH 効果を示すエビデンスを示さないも のも多かった ${ }^{18,19)}$ 。近年, Vosenin ${ }^{13)}$ が, レ 
ビューをおこなったが，正常大気圧で行われた 細胞実験では，ことごとく FLASH 効果の証明 に失敗している一方で, 細胞を低酸素下におい た場合, FLASHでの保護効果が認められ，防 御効果は $1.1 〜 3$ 倍程度であった。このことか ら, 酸素がFLASH にとって大きな意味を持つ ことが推察されている。Adrian ${ }^{20)}$ は, 正常酸 素下と $1.6 \%$ の低酸素下における通常線量率と FLASH-RT での生存率を検討したところ, 正常 酸素下では, FLASH 効果が認められないこと を，また低酸素化で，18Gy 以上と 1 回線量が 大きい場合に，有意差を持って FLASHによる 保護効果が認めたことを報告している。また, 1 回線量 $18 \mathrm{~Gy}$ を固定した場合には, $4.4 \%$ の酸 素濃度以下で, FLASHの保護効果を認めた。 また, Buonanno ら ${ }^{21)}$ は, 正常肺線維芽細胞 （IMR90）に対して, 正常酸素化で低エネルギー 陽子線 $(4.5 \mathrm{MeV})$ による FLASH-RT $(1000 \mathrm{~Gy} / \mathrm{s})$ を行った。結果としては, コロニー試験におい ての保護効果 (生存率)に差はなかったが, 長 期にわたる放射線誘発性の老化と TGF- $\beta 1$ の発 現が軽減されることを報告した。FLASH-RTの 線量率の定義として，疑問は残る報告であった が, このように生存以外の表現型に差がでるこ とがこれ以外にも多数示されている ${ }^{22) 。 ~}$

\section{6. 「FLASH」効果のメカニズムに関する仮説}

$\lceil\mathrm{FLASH} 」$ 効果のメカニズムは現時点では解 明されていないが，いくつかの仮説がたてられ ている。これらの仮説のどれか，もしくはその 複合的なものがメカニズムとして機能している と考えられる。本総説では, その仮説をいくつ か紹介する。

\section{$6 \cdot 1$ 酸素枯渇仮説}

$\lceil\mathrm{FLASH}-\mathrm{RT} 」$ $「 \mathrm{CONV}-\mathrm{RT} 」$ の間で, このよ うな組織応答に違いがあるのは, 超高線量率で は酸素の放射線化学的枯渴が生じることによる ものであり，その結果，照射した組織に放射線 抵抗性が生じるという考えを一部の研究者達が
示唆している ${ }^{23-25)}$ 。酸素供給が十分になされ ている組織よりも低酸素状態の組織のほうが, 放射線抵抗性が高い。酸素分子が存在すると, 間接的な放射線誘発性 DNA 損傷が起こりやす いからである。低 LET 放射線が DNA 損傷を誘 導する主な機序である間接的損傷は，放射線に より水が分解され，生じるヒドロキシラジカル (·OH）などのフリーラジカルによるものであ る。しかし，これは容易に還元物質 (スカベン ジャー, SH 基を有するグルタチオンなど）で 解消できる。しかし, 酸素分子と反応すると, ペルオキシラジカル (ROO·) が生じ，永続的な 損傷を誘発するため, より効果の高い DNA 損 傷を生み出す。したがって, 細胞のすぐ近傍 に酸素がなければ，放射線誘発性 DNA 損傷が 抑えられることになる。照射された細胞内にお いて, 放射線化学的な酸素枯渇は, 酸素の量と 照射された量に依存することがわかっている が26)，FLASH-RTよる酸素消費は，CONV-RT の数千倍で, 特に血管から遠い細胞では, 血液 からの酸素供給が追いつかず，酸素欠そが生じ ることがわかっている ${ }^{24)}$ 「FFLASH-RT」のよう な超高線量率での照射をすると, 細胞内の酸素 が一瞬で消費されるため, 普段酸素がある程度 存在する正常細胞においては, 低酸素状態にな るため,「治療抵抗性」=「生存率が上昇」とい う形になる。腫瘍細胞においては，もともと極 めて低酸素な環境であり, その効果が少ないと いわれている。また，局所的及び一時的な酸素 の枯渇に加えて，ラジカルとラジカルの相互作 用も関与しているといわれている。FLASH-RT によって，高い局所ラジカル濃度となり，ラ ジカルーラジカル相互作用をもたらす。その結 果, DNA と相互作用するために利用できるフ リーラジカルが少なくなり，障害が少なくなる わけであり ${ }^{3,27)}$, いわゆる活性酸素種 (reactive oxygen species, ROS）の産生が減ることになる。 この現象も Montay-Gruel ら ${ }^{28)}$ によって報告さ れている。Spitzらは26), FLASHにより発生し たラジカルの処理能力が, 腫瘍と正常細胞で異 
なり,これが最終的に DNA 損傷の違いに繋が る可能性があるということも報告している（不 安定な鉄のプールの違い, 正常組織ではフェン トン反応は少ない)。上記のAdrian ら ${ }^{20)}$ の報 告のように, in vitroの環境では, 低酸素組織 で起こりやすく, 正常酸素組織や逆に無酸素 組織だと FLASH 効果は起こらない。すなわち FLASH 効果には酸素が鍵になる。FLASH-RT による酸素枯渇に関しては, シミュレーション によって多数報告されているが29,30), いわゆ る外挿されたもので, 直接酸素枯渇を測定した ものではなかった。最近, Kusumoto ら ${ }^{31)}$ は, クマリン-3-カルボン酸 (C3CA) と呼ばれる $\mathrm{OH}$ ラジカルと反応すると蛍光を発する水溶液に対 して, 陽子線で FLASH-RT と CONV-RT で比較 したところ, FLASH 照射では蛍光量が $1 / 3$ と 少なったことを報告している。FLASH では一 瞬の照射の間に水溶液中に陽子線の飛跡が密に 存在し, 飛跡近傍の酸素分子は他の水の放射線 分解生成物 (水和電子や水素ラジカル等) との 反応で先に使われるため, 酸素分子が介在した $\mathrm{OH}$ ラジカルとの反応で生成する蛍光量が大き く減少した。つまり, 超高線量率で照射された 陽子線の飛跡近傍の低酸素化が起きている事を 明らかにした。

\section{$6 \cdot 2$ 免疫仮説}

免疫応答の違いが変化するという考えも, FLASH 効果の想定される機序として提唱され ている ${ }^{23)}$ 。CONV-RT は FLASH-RTと比較し て, 照射を受ける循環リンパ球の割合が高く なる ${ }^{31)}$ 。つまり，FLASH-RTに特徵的な照射 時間が短いことにより，照射を受けるリンパ 球の数が少なくなり, その結果, 染色体異常 の誘導が低下することになる ${ }^{23,32)}$ 。この仮説 は, FLASH-RT 及び CONV-RT 後のマウスに, マイクロアレイ解析を行った研究で可能性が増 した ${ }^{11)}$ 。その研究では, CONV-RTと比較して FLASH-RT 後のマウスでは, 免疫系全体の活性 化及び成熟が弱められていることが報告され

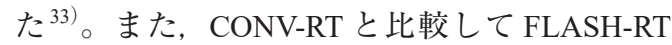
治療を受けた腫瘍については, 腫瘍周囲の微小 環境への Tリンパ球の動員が向上しているこ とを示したことも ${ }^{34,35)}$ ，この仮説を強化する ものであると言える。しかし, FLASH 効果は, 細菌培養モデルや細胞培養モデルの in vitro で も観察されており, それらのモデルには, 機能 する免疫系がないため, 免疫学的コンポーネン トがあったとしても, 背景機序の一部しか担っ ていないと考えられる。

$6 \cdot 3$ 炎症反応 /サイトカイン抑制など DNA 応答が異なるという仮説

正常細胞において,「FLASH」条件での照射 を行うと, DNA 応答が異なり, 細胞死が抑制 されるという仮説も報告されている。上記の ごとく, Buonanno ら ${ }^{21)}$ は, 正常肺線維芽細胞 （IMR90）において, コロニー試験においての 保護効果 (生存率) に差はなかったが, 長期に わたる放射線誘発性の老化と TGF- $\beta 1$ の発現 が軽減されることを報告している。また Fouillade ら ${ }^{22)}$ は, FLASH が, 炎症性遺伝子の誘導 と DNA 損傷の持続を最小限に抑え, 肺前駆細 胞を温存し, 放射線誘導による細胞老化の発生 を抑えることで放射線からの回復を促進すると いうことを報告している。しかし，これらの研 究では, 大気と平衡状態に置かれた培養環境で 維持された正常な細胞に対して, 異なるDNA 損傷を FLASH が誘発させることも報告してい る。これは腫瘍細胞とは共有しない特性である ため, 酸素だけがFLASH 効果に唯一介在する 物質ではなく, 細胞分裂周期の進行とフリーラ ジカルのような酸素枯渇仮説などの, DNA 修 復に関連するメカニズムの一部かもしれない。

\section{7. 「FLASH」効果が実臨床に期待される}

$\lceil\mathrm{FLASH} 」$ の臨床への移行を支持する主な デー夕を, Bourhis や Wilson ら ${ }^{16,36)}$ がレビュー しているが, 彼らは, その妥当性, 臨床試験 が成功するのに必要な主な照射パラメー夕（線 
量，パルス内の線量率，合計照射時間）ならび に必要となると思われる技術について検討し ている。特に, その条件としては, 1 shot, 線 量率が 40-100 Gy/s 以上, 1 回線量が 8-10 Gy 以 上，総照射時間が $0.1-0.2$ 秒以内というように, 境界領域の設定值に関しては, 議論が続いてい る状態である。そのような中で, Bourhis ら ${ }^{37)}$ が, 臨床で FLASH 効果を評価するのに必要な 明示的な条件を有する最初の患者の治療を行っ たことを世界で初めて報告した。全身の皮膚表 面に播種している $\mathrm{CD} 30+$ 悪性 $\mathrm{T}$ 細胞性皮膚リ ンパ腫の 75 歳の患者が対象であった。それま で様々な潰瘍性や疼痛を伴う皮膚病変のための 局所皮膚放射線治療を受け, 全身治療を行っ たにもかかわらず進行し, 全身の忍容性が低 い状態であった。つまり, 本症例では FLASHRT 治療の前に, 数十回の放射線治療歴があっ た。実際の「FLASH-RT」は, FLASH のために 改造された LINAC からの 5.6-MeV の電子線で, 幅 $1 \mu \mathrm{s}$ のパルスを $10 \mathrm{~ms}$ の間隔で 10 回, $90 \mathrm{~ms}$ に $15 \mathrm{~Gy}$ の線量を照射して, 直径 $3.5 \mathrm{~cm}$ の皮膚 腫瘍を治療した。5ケ月間の短期追跡では, 腫 瘍の応答は $\mathrm{CR}$ で, 腫瘍の周囲の軟部組織に グレード1の上皮炎と一過性のグレード 1 浮 腫を認めたのみであった。光干涉断層法では, FLASH-RTで, 表皮と基底膜の厚さが温存さ れ，血管系に限定的な損傷のみが生じているこ とが示され，これらの臨床結果は非常に有望な ものであったと考えられた。その後, 現状では 少しずつ臨床試験が始まろうとしているところ である。「FLASH-RT」は，照射時間の制約が厳 しい条件で, 極めて短時間に 1 回もしくは低分 割照射を行う，ということが予想される。つま り, 裏返して考えると, 一瞬で照射が終わるた め (照射範囲にもよるが), 動く腫瘍や臓器の 治療を容易にし（特にスキャニング照射のよう なペンシルビームアプローチ*1《加速器からの 細いビームを走査電磁石で調節し, ターゲット を塗りつぶすような照射方法》を用いた場合), それに伴う interplay 効果*2 (骨と標的の動き
が，干渉することにより，過大もしくは過小線 量を生じること）のリスクを低減させること, ならびに分割照射間の位置ずれや不確かさが増 すリスクを最小限に押さえて治療ができる可能 性がある。また, 有害事象を軽減できれば, 総 線量をあげることで, 抗腫瘍効果をあげられる 可能性がある。すなわち, 治療効果比を上昇さ せることが期待できる。

\section{8. 「FLASH」を実現するための機器の考察と 実際の例}

現状においては, 実験や臨床試験として実際 に使用されたほとんどの機器は, 実験機や X 線 リニアックに改造を施し, 電子線を活用したもの である ${ }^{38,39)}$ 。実際にX 線では, FLASH 条件を満 たすような線量率を生み出すのに, 電子線の約 200 倍の出力が必要といわれている。X 線による 新たな治療機器の構想もあり, 開発がされてい るようではあるが，まだまだ実現への道は険し い。つまり, 実際には表在性の腫瘍や, 術中照 射がメインになってしまい, 実臨床となると非常 に限られた疾患・条件が対象となることが予想 される。近年においては, 陽子線の機器開発も 進み, 陽子線治療の利用者の中で積極的に研究 を推進していることもあり, テクニカルソリュー ションや手順に関していくつかの特許がすでに 取得されてきている。いわゆる実臨床器の陽子 線治療器を使用して, FLASHの条件を満たす 線量率を出力することはすでに可能であり ${ }^{40,41)}$, 電子線と比較して, より深いターゲットへの照射 も可能になるが, 現状では, 非常に照射範囲が 狭く，限定的であることが課題である ${ }^{42)}$

Jolly ら $^{43)}$ は, 陽子線の加速器別の治療機器 に関して，違いや課題を報告している。表1の ように, どの加速器の方式でも, 「FLASH」は 可能ではあるが, 極めて高い線量率を生じさ せるには, シンクロトロンよりもサイクロト ロンやシンクロサイクロトロンがより適して いるかもしれない。しかし, サイクロトロン では，エネルギーが一定のため,「FLASH」の 
線量率を満たすビームは，治療台の上におい て，プラトービーム*3 (Bragg peak 前の入射面 からしばらくはほぼ一様の飛程部分) による照 射しか不可能であり（機械内で照射を行えばこ れに限らない)，これまでの実験の報告もプラ トービームが使用されてきた。これでは，陽 子線の特徵である Bragg peak を活かすことは できない。Bragg peak 作成には，照射経路に拡 大 Bragg peak 形成装置 (リッジフィルターやレ ンジモジュレーションホイールなど) が必要に なるが，それを通過することで線量率が下がる ため, FLASH の要件を満たさなくなる可能性 がある。もちろん，ピークのビームを使用する ということはLETが上昇するため, LET の上 昇により FLASH 効果が失われないのか, 確認 が必要ではあるが, シンクロトロンではエネル ギー可変のため, この点に打いては有利とな る。また, シンクロサイクロトロンは非常に短 い時間で少ない電荷量を照射，それを高い頻度 （1 秒間に1000 回）で繰り返す方式なので，ス キャニング照射ではその運転繰返し周期ごとに スポットに照射していくと，1つ1つのスポッ トへの照射量が少なく，それ単発ではFLASH 条件を満たさない可能性が高い（線量率は OK でも 1 回照射量が足りない)。したがって, 散 乱体で拡大したほうが FLASH 条件を満たすこ とができる，ただし大きな照射野までは拡大 できない。シンクロトロンでもし 1 ショット で FLASH 条件を満たすことができれば，それ を繰り返し照射することでスキャニングでの FLASH 治療ができる可能性がある。それぞれ の治療器では，すでに小さなターゲットへの実 験アプローチでは, 高い線量率が得られること が示されていて, ブロードビーム照射*4（ビー ムを病変の形状広げて，ビームの束を照射する 方法) やスキャニング照射*5（加速器からの細 いビームを走査電磁石で調節し, ターゲットを 塗りつぶすような照射方法）を用いた実験がす でに実施されている。しかし，スキャニング照 射の効果については今後解明する課題が多い。
ターゲット形状にあった「FLASH-RT」が可能 になると考えられるが，腫瘍全体に照射するの には，時間がかかりすぎる ${ }^{14,44)}$ 。連続するス ポットとエネルギー層の重なり合いが，どの程 度に設定できるかで異なってくるが，重なり合 う部分の FLASH 効果がどうなるのかなどもま だ解明が必要である。現時点では, 陽子線治療 はスキャニング照射が主流になってきている が,「FLASH」に関しては，上述のようにwobbler 法*6 (ワブラー電磁石のような回転磁場で 照射野を形成する方法) などブロードビームの 照射の方が照射範囲の確保にも適しているか もしれない。この他，「FLASH」照射の深さ方 向を担保するため, 3D プリンターなどでミニ リッジフィルターなどを作成した実験なども行 われているが45), 今後, 患者毎の腫瘍の形状 に合わせたフィルターを使用した「FLASH」照 射などの開発が期待される。

実臨床へ向けては，これらの治療機器の開発 以外にも，測定の確立が必要である ${ }^{46)}$ 。わず かなずれや線量率の低下で条件を満たさなくな ることもあるかもしれない。また実際の治療計 画機への反映も必要である, 線量率や細胞個々 によっても実際の反応が異なってくる可能性が あり，それらをどう取り入れることができるの か，また評価することができるのか，まだまだ 課題が多い44)。

名古屋市立大学医学部附属西部医療センター (名古屋陽子線治療センター) では, シンクロト ロン加速器を使用した陽子線治療器 (PROBEATIII，日立製作所製）によるFLASH-RT での基礎 実験を行っている。実際の,「FLASH」条件を 満たすために, シンクロトロン加速器を使用し て通常 4 秒以上かけて取り出している陽子を, 高周波パワーの印加パターンを調整して短時間 化し，さらにパッシブ照射*7（ブロードビーム 法の一種，散乱体を使用しビームを広げる）用 の入射条件を一部適用し，蓄積される陽子の 量を通常のスキャニング運転の約 2 倍に増やし た。その陽子を $50 \mathrm{~ms}$ 程度で全て取り出せるよ 
表1 Summary of features of accelerators applied to proton therapy

\begin{tabular}{|c|c|c|c|c|c|c|c|}
\hline \multirow[b]{2}{*}{ ベンダ } & \multirow[b]{2}{*}{1} & \multicolumn{2}{|c|}{$\begin{array}{l}\text { 等時性 } \\
\text { サイクロトロン }\end{array}$} & \multicolumn{2}{|c|}{$\begin{array}{l}\text { シンクロ } \\
\text { サイクロトロン }\end{array}$} & \multirow{2}{*}{$\begin{array}{l}\text { シンクロ } \\
\text { トロン } \\
\text { Hitachi }\end{array}$} & \multirow{2}{*}{$\frac{\text { 線型加速器 }}{\text { AVO }}$} \\
\hline & & IBA & Varian & IBA & Mevion & & \\
\hline システム名 & 2 & $\mathrm{C} 230$ & PROBEAM & $\mathrm{S} 2 \mathrm{C} 2$ & S250 & PROBEAT & LIGHT \\
\hline $\begin{array}{l}\text { 最大エネル } \\
\text { ギー[MeV] }\end{array}$ & 3 & 230 & 250 & 250 & 250 & 250 & 250 \\
\hline $\begin{array}{l}\text { 最低エネル } \\
\text { ギー[MeV] }\end{array}$ & 4 & 70 & 70 & 70 & 70 & 70 & 37.5 \\
\hline $\begin{array}{c}\text { ピーク電流 } \\
\qquad \mu \mathrm{A}]\end{array}$ & 5 & 0.3 & 0.8 & $\sim 18$ & $\sim 7$ & $4.8 \times 10^{-3 *}$ & $\sim 40$ \\
\hline $\begin{array}{l}\text { 最大平均 } \\
\text { 電流 }[\mathrm{nA}]\end{array}$ & 6 & 300 & 800 & $\sim 130$ & $\sim 32$ & 4.8 & 32 \\
\hline 繰り返し & 7 & $\mathrm{CW}$ & $\mathrm{CW}$ & $1 \mathrm{kHz}$ & $500-750 \mathrm{~Hz}$ & $\mathrm{CW}$ & $200 \mathrm{~Hz}$ \\
\hline $\begin{array}{l}\text { ビーム } \\
\text { パルス長 }\end{array}$ & 8 & $>400 \mu \mathrm{s}$ & $>400 \mu \mathrm{s}$ & $7 \mu \mathrm{s}$ & $6 \mu \mathrm{s}$ & $0.5 \sim 5 \mathrm{~s}$ & $4 \mu \mathrm{s}$ \\
\hline 特徵 & 9 & \multicolumn{2}{|c|}{ 連続的な電流を照射 } & \multicolumn{2}{|c|}{$\begin{array}{c}\text { 極短パルスを } \\
\text { 早い繰り返しで照射 }\end{array}$} & 間欠的な照射 & $\begin{array}{c}\text { 極短パルスを } \\
\text { 早い繰り返し } \\
\text { で照射 }\end{array}$ \\
\hline $\begin{array}{c}\text { 陽子 } \\
\text { エネルギー }\end{array}$ & 10 & 最大エオ & ルギー固定 & 最大エ & ルギー固定 & 可変 & 可変 \\
\hline
\end{tabular}

No. 1 to 8 are partially excerpted from the paper by Jolly et al. ${ }^{43)}$ and modified, and No. 9 and 10 are added by the author.

*As described below, irradiation of $0.1-0.2 \mu \mathrm{A}$ is possible at Nagoya City University West Medical Center (Nagoya Proton Therapy Center).

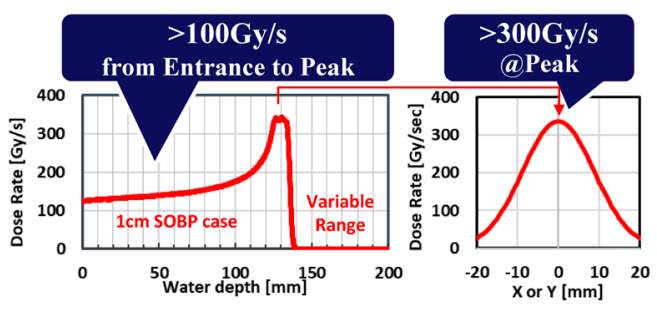

図2 Measured dose rate. FLASH-RT using a synchrotron accelerator. Both entrance (plateau) and peak irradiation can satisfy the FLASH condition at the Nagoya Proton Therapy Center (Color online).

う通常の数十倍の高周波パワーを印加し, シン クロトロン取り出し直後のファラディカップ*8 (帯電した粒子を真空中で捕捉する装置) で観 測, 波形を調整するなどして, 超高線量率照 射を実現した（図2）。ガラス，フィルム，Advanced Markus ${ }^{* 9}$ Chamber $^{\circledR}$ (平行平板形電離箱)
にて線量・線量率を測定しているが, 実際の照 射例を図3に示す。現状では, 諸条件を調整し ながら, シンクロトロン加速器でのメリットを 活かせるように, 多数の実験を行っている ${ }^{47) 。 ~}$

\section{9. おわりに}

本総説で述べたように「FLASH-RT」は放射 線治療の歴史において革命的なもので, 今後の 実臨床への応用に非常に期待される。一部の皮 膚腫瘍などで実臨床が始まっているが, 道はま だ険しい。メカニズムの解明, 照射機器の更な る発展・開発, 線量測定方法の確立などが不可 欠である。つまり,「FLASH-RT」の成功には, 臨床と基礎の融合が必要である。確かな基礎研 究に裏打ちされた技術開発には, 臨床家と研究 者の共同での努力, ならびに産学官連携が必須 


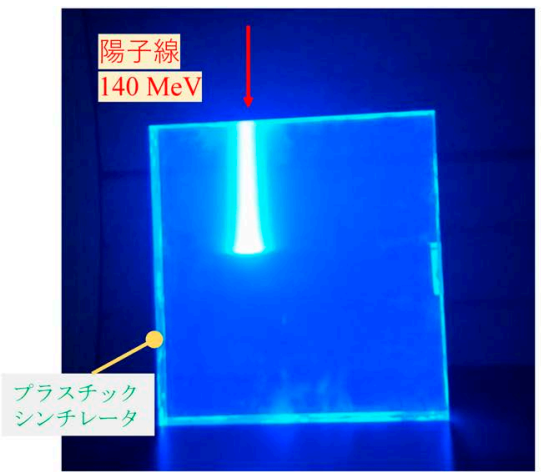

超高線量率照射 (FLASH)

$340 \mathrm{~Gy} / \mathrm{s}$

$17 \mathrm{~Gy} / \mathrm{shot}$

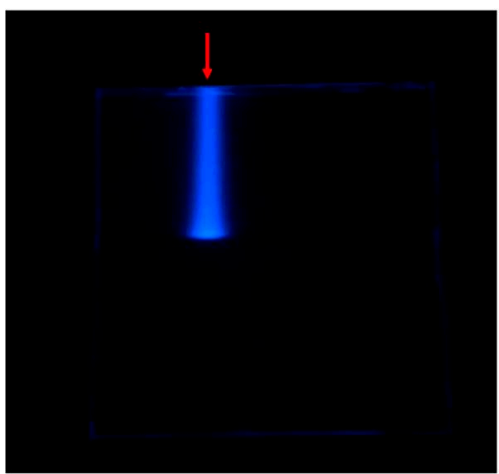

通常線量率照射 (Conventional)

$1.5-3 \mathrm{~Gy} / \mathrm{s}$

$7 \mathrm{~Gy} / \mathrm{shot}$

図3 Actual example of FLASH-RT. The difference in brightness with respect to the plastic scintillator indicates that FLASH-RT irradiates a higher dose within the same time than conventional-RT (ultra-high dose rate irradiation). (at the Nagoya Proton Therapy Center) (Color online).

である。一部の海外企業においては,「FLASH」 に関するコンソーシアムを立ち上げ, 国の補助 金を獲得するなど，研究体制を整え，実臨床へ つなげる努力をしている。日本国内においても， 企業, もしくは学会・研究会などが主導となる ような大きな枠組みでの取り組みが期待される。 具体的には,「FLASH-RT」の条件の明確化, 原 理・現象の解明, 実験系の確立, 治療器の開発, 治療測定手技の確立などが今後の課題である。 本総説で紹介した陽子線による「FLASH」に ついては, 筆者が所属する名古屋市立大学医学 部附属西部医療センター（名古屋陽子線治療セ ンター）において実施が可能である。日本国内 に押いては, 数限られた実施可能な照射施設で あり, 将来的には, 他の研究者との共同研究や 実臨床が，大いに期待される。「FLASH」に関 して, 共同での研究をご希望される先生方から のご連絡を心待ちにしている。

\section{文献}

1) Jang, B. S., Cha, M. J., Kim, H. J., Oh, S., et al., Heart substructural dosimetric parameters and risk of cardiac events after definitive chemoradiotherapy for stage III non-small cell lung cancer, Radiother.
Oncol., 152, 126-132 (2020)

2) Iwata, H., Akita, K., Yamaba, Y., Kunii, E., et al., Concurrent chemo-proton therapy using adaptive planning for unresectable stage III non-small cell lung cancer: A phase II study, Int. J. Radiat. Oncol. Biol. Phys., article in press, (2020) S0360-3016(20)34557-0

3) Berry, R. J., Hall, E. J., Forster, D. W., Storr, T. H., et al., Survival of mammalian cells exposed to $\mathrm{x}$ rays at ultra-high dose-rates, Br. J. Radiol., 42, 102-107 (1969)

4) Weiss, H., Epp, E. R., Heslin, J. M., Ling, C. C., et al., Oxygen depletion in cells irradiated at ultra-high dose-rates and at conventional dose-rates, Int. J. Radiat. Biol. Relat. Stud. Phys. Chem. Med., 26, 17-29 (1974)

5) Favaudon, V., Caplier, L., Monceau, V., Pouzoulet, F., et al., Ultrahigh dose-rate FLASH irradiation increases the differential response between normal and tumor tissue in mice, Sci. Transl. Med., 6, 245ra93 (2014)

6) Montay-Gruel, P., Petersson, K., Jaccard, M., Boivin, G., et al., Irradiation in a flash: Unique sparing of memory in mice after whole brain irradiation with dose rates above $100 \mathrm{~Gy} / \mathrm{s}$, Radiother. Oncol., 124, 365-369 (2017)

7) Simmons, D. A., Lartey, F. M., Schüler, E., Rafat, M., et al., Reduced cognitive deficits after FLASH irradiation of whole mouse brain are associated with less hippocampal dendritic spine loss and neuroinflammation, Radiother. Oncol., 139, 4-10 (2019) 
8) Field, S. B. and Bewley, D. K., Effects of dose-rate on the radiation response of rat skin, Int. J. Radiat. Biol. Relat. Stud. Phys. Chem. Med., 26, 259-267 (1974)

9) Vozenin, M. C., De Fornel, P., Petersson, K., Favaudon, V., et al., The advantage of FLASH radiotherapy confirmed in mini-pig and cat-cancer patients, Clin. Cancer Res., 25, 35-42 (2019)

10) Levy, K., Natarajan, S., Wang, J., Chow, S., et al., Abdominal FLASH irradiation reduces radiationinduced gastrointestinal toxicity for the treatment of ovarian cancer in mice, Sci. Rep., 10, 21600 (2020)

11) Smyth, L. M. L., Donoghue, J. F., Ventura, J. A., Livingstone, J., et al., Comparative toxicity of synchrotron and conventional radiation therapy based on total and partial body irradiation in a murine model, Sci. Rep., 8, 12044 (2018)

12) Beyreuther, E., Brand, M., Hans, S., Hideghéty, K., et al., Feasibility of proton FLASH effect tested by zebrafish embryo irradiation, Radiother. Oncol., 139, 46-50 (2019)

13) Vozenin, M. C., Hendry, J. H. and Limoli, C. L., Biological benefits of ultra-high dose rate FLASH radiotherapy: Sleeping beauty awoken, Clin. Oncol. (R. Coll. Radiol.), 31, 407-415 (2019)

14) Montay-Gruel, P., Bouchet, A., Jaccard, M., Patin, D., et al., X-rays can trigger the FLASH effect: Ultrahigh dose-rate synchrotron light source prevents normal brain injury after whole brain irradiation in mice, Radiother. Oncol., 129, 582-588 (2018)

15) Chabi, S., To, THV., Leavitt, R., Poglio, S., et al., Ultra-high-dose-rate FLASH and conventional-doserate irradiation differentially affect human acute lymphoblastic leukemia and normal hematopoiesis, Int. J. Radiat. Oncol. Biol. Phys., article in press (2020) S0360-3016(20)34400-X

16) Bourhis, J., Montay-Gruel, P., Goncalves, J. P., Bailat, C., et al., Clinical translation of FLASH radiotherapy: Why and how? Radiother. Oncol., 139, 11-17 (2019)

17) Zlobinskaya, O., Siebenwirth, C., Greubel, C., Hable, V., et al., The effects of ultra-high dose rate proton irradiation on growth delay in the treatment of human tumor xenografts in nude mice, Radiat. Res., 181, 177-183 (2014)

18) Auer, S., Hable, V., Greubel, C., Drexler, G. A., et al., Survival of tumor cells after proton irradiation with ultra-high dose rates, Radiat. Oncol., 6, 139 (2011)

19) Shinohara, K., Nakano, H., Miyazaki, N., Tago, M., et al., Effects of single-pulse ( $<$ or $=1 \mathrm{ps}) \mathrm{X}$-rays from laser-produced plasmas on mammalian cells, J. Radiat. Res. (Tokyo), 45, 509-514 (2004)

20) Adrian, G., Konradsson, E., Lempart, M., Bäck, S., et al., The FLASH effect depends on oxygen concentration, Br. J. Radiol., 93, 20190702 (2020)

21) Buonanno, M., Grilj, V. and Brenner, D. J., Biological effects in normal cells exposed to FLASH dose rate protons, Radiother. Oncol., 139, 51-55 (2019)

22) Fouillade, C., Curras-Alonso, S., Giuranno, L., Quelennec, E., et al., FLASH irradiation spares lung progenitor cells and limits the incidence of radio-induced senescence, Clin. Cancer Res., 26, 1497-1506 (2020)

23) Durante, M., Bräuer-Krisch, E. and Hill, M., Faster and safer? FLASH ultra-high dose rate in radiotherapy, Br. J. Radiol., 91, 20170628 (2018)

24) Wilson, P., Jones, B., Yokoi, T., Hill, M., et al., Revisiting the ultra-high dose rate effect: Implications for charged particle radiotherapy using protons and light ions, Br. J. Radiol., 85, e933-e939 (2012)

25) Pratx, G. and Kapp, D. S., Ultra-high-dose-rate FLASH irradiation may spare hypoxic stem cell niches in normal tissues, Int. J. Radiat. Oncol. Biol. Phys., 105, 190-192 (2019)

26) Spitz, D. R., Buettner, G. R., Petronek, M. S., StAubin, J. J., et al., An integrated physico-chemical approach for explaining the differential impact of FLASH versus conventional dose rate irradiation on cancer and normal tissue responses, Radiother. Oncol., 139, 23-27 (2019)

27) Grimes, D. R. and Partridge, M., A mechanistic investigation of the oxygen fixation hypothesis and oxygen enhancement ratio, Biomed. Phys. Eng. Express, 1, 045209 (2015)

28) Montay-Gruel, P., Acharya, M. M., Petersson, K., Alikhani, L., et al., Long-term neurocognitive benefits of FLASH radiotherapy driven by reduced reactive oxygen species, Proc. Natl. Acad. Sci. USA, 116, 10943-10951 (2019)

29) Pratx, G. and Kapp, D. S., A computational model of radiolytic oxygen depletion during FLASH irradiation and its effect on the oxygen enhancement ratio, Phys. Med. Biol., 64, 185005 (2019)

30) Labarbe, R., Hotoiu, L., Barbier, J. and Favaudon, V., A physicochemical model of reaction kinetics supports peroxyl radical recombination as the main determinant of the FLASH effect, Radiother Oncol, article in press (2020) S0167-8140(20)30308-X

31) Kusumoto, T., Kitamura, H., Hojo, S., Konishi, T., et al., Significant changes in yields of 7-hydroxy- 
coumarin-3-carboxylic acid produced under FLASH radiotherapy conditions, RSC Advances, 10, 3870938714 (2020)

32) Yovino, S., Kleinberg, L., Grossman, S. A., Narayanan, M., et al., The etiology of treatment-related lymphopenia in patients with malignant gliomas: Modeling radiation dose to circulating lymphocytes explains clinical observations and suggests methods of modifying the impact of radiation on immune cells, Cancer Invest., 31, 140-144 (2013)

33) Girdhani, S., Abel, E., Katsis, A., Rodriquez, A., et al., FLASH: A novel paradigm changing tumor irradiation platform that enhances therapeutic ratio by reducing normal tissue toxicity and activating immune pathways, Cancer Res., 79, LB-280 (2019)

34) Rama, N., Saha, T., Shukla, S., Goda, C., et al., Improved tumor control through t-cell infiltration modulated by ultra-high dose rate proton FLASH using a clinical pencil beam scanning proton system, Int. J. Radiat. Oncol. Biol. Phys., 105, S164-S165 (2019)

35) Jin, J. Y., Gu, A., Wang, W., Oleinick, N. L., et al., Ultra-high dose rate effect on circulating immune cells: A potential mechanism for FLASH effect? $R a$ diother. Oncol., 149, 55-62 (2020)

36) Wilson, J. D., Hammond, E. M., Higgins, G. S. and Petersson, K., Ultra-high dose rate (FLASH) radiotherapy: Silver bullet or fool's gold? Front. Oncol., 9, 1563 (2020)

37) Bourhis, J., Sozzi, W. J., Jorge, P. G., Gaide, O., et al., Treatment of a first patient with FLASHradiotherapy, Radiother. Oncol., 139, 18-22 (2019)

38) Jaccard, M., Durán, M. T., Petersson, K., Germond, J. F., et al., High dose-per-pulse electron beam dosimetry: Commissioning of the Oriatron eRT6 prototype linear accelerator for preclinical use, Med. Phys., 45, 863-874 (2018)

39) Schüler, E., Trovati, S., King, G., Lartey, F., et al., Experimental platform for ultra-high dose rate FLASH irradiation of small animals using a clinical linear accelerator, Int. J. Radiat. Oncol. Biol. Phys., 97, 195-203 (2017)

40) Diffenderfer, E. S., Verginadis, I. I., Kim, M. M., Shoniyozov, K., et al., Design, implementation, and in vivo validation of a novel proton FLASH radiation therapy system, Int. J. Radiat. Oncol. Biol. Phys., 106, 440-448 (2020)

41) Colangelo, N. W. and Azzam, E. I., The importance and clinical implications of FLASH ultra-high doserate studies for proton and heavy ion radiotherapy, Radiat. Res., 193, 1-4 (2020)

42) Zou, W., Diffenderfer, E. S., Cengel, K. A., Kim, M. M., et al., Current delivery limitations of proton PBS for FLASH, Radiother. Oncol., 155, 212-218 (2020)

43) Jolly, S., Owen, H., Schippers, M. and Welsch, C., Technical challenges for FLASH proton therapy, Phys. Med., 78, 71-82 (2020)

44) van de Water, S., Safai, S., Schippers, J. M., Weber, D. C., et al., Towards FLASH proton therapy: The impact of treatment planning and machine characteristics on achievable dose rates, Acta Oncol., 58, 1463-1469 (2019)

45) Patriarca, A., Fouillade, C., Auger, M., Martin, F., et al., Experimental set-up for FLASH proton irradiation of small animals using a clinical system, Int. $J$. Radiat. Oncol. Biol. Phys., 102, 619-626 (2018)

46) Snyder, M., Vadas, J., Musselwhite, J., Halford, R., et al., Technical Note: FLASH radiotherapy monitor chamber signal conditioning, Med. Phys., article in press, (2020)

47) Iwata, H., Ogino, H., Hattori, Y., Hashimoto, S., et al., Phase II study of image-guided proton therapy for solitary primary hepatocellular carcinoma with indication for standard treatment, Int. J. Radiat. Oncol. Biol. Phys., 108S, E522 (2020)

\section{Abstract}

\section{FLASH Radiotherapy}

Hiromitsu Iwata ${ }^{1,2, \dagger}$ and Yuta Shibamoto $2:{ }^{1}$ Department of Radiation Oncology, Nagoya Proton Therapy Center, Nagoya City University West Medical Center, ${ }^{2}$ Department of Radiology, Nagoya City University Graduate School of Medical Sciences, ${ }^{\dagger}$ h-iwa-ncu@nifty.com

FLASH Radiotherapy is an ultra-high dose rate irradiation, and has a characteristic of reducing the normal tissue damage. Therefore, it overturns the conventional concept of radiotherapy, and if it can be applied clinically, it has the potential to produce a paradigm shift in the field of radiotherapy. In this review, we introduce the background, biological aspects, mechanism, and efforts for clinical application. 